Arch. Tierz., Dummerstorf 43 (2000) 2, 131-137

Federal Centre for Meat Research, Institute for Meat Production and Market Research, Kulmbach, Germany

WOLFGANG BRANSCHEID and ANDREAS DOBROWOLSKI

\title{
Evaluation of market value: comparison between different techniques applied on pork carcasses (short communication)
}

\begin{abstract}
Summary
The market value of a carcass in the whole should be represented by the sum of values of all single cuts dissected from a carcass. These values of the single cuts are defined by their tissue composition and meat quality characteristics $(\mathrm{pH}$, etc.)respectively. The fixing of market value at the slaughter line requires very quick methods that base on instrumental measurements and electronic data management. Nowadays four technically different types of instruments are available for the determination of market value in Germany. Following instrumental devices are compared and valuated. Opto-electronic devices, Ultrasonic scanners, Autoform (SFK company, DK), The video imaging system VCS 2000. These four technical systems presented in this study give equally good results in predicting the market value of pork carcass. It can state, that the fully automatic devices represent a new stage of development. They are calculating the market value on a great number of measurements and in most aspects with a high reliability.
\end{abstract}

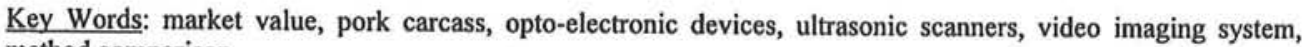
method comparison

\section{Zusammenfassung}

Titel der Arbeit: Bestimmung des Handelswertes - Vergleich von MeBmethoden bei Schweinehălften (Kurzmitteilung)

Der Handelswert von Schweinehalften wird repräsentiert durch die Summe ihrer Teilstucke. Der Wert der Teilstücke ergibt sich aus deren Gewebezusammensetzung und den Fleischqualitatsmerkmalen. Die Bestimmung des Handelswertes an der Schlachtlinie erfordert schnelle Methoden mit Meßgeräten und elektronischer Datenverarbeitung. Derzeit sind in Deutschland vier Gerătetypen zur Bestimmung des Handelswertes verfugbar. Es werden folgende Gerätetypen beschrieben und bewertet: Optisch-elektronische Geräte, Ultraschallscanner, Autoform und das Video-Image-System VCS 2000. Es wird nachgewiesen, daß die Systeme vergleichbar gute Ergebnisse zur Schlachthälftenbewertung ergeben. Die vollautomatisch arbeitenden Geräte stellen eine neue Entwicklungsstufe dar. Sie berechnen den Handelswert mit hoher Zuverlăssigkeit aus einer großen Anzahl von Meßwerten.

Schlüsselwörter: Handelswert, Schweinehălften, Optisch-elektronische Gerăte, Ultraschallscanner, VideoImage-System, Methodenvergleich

\section{Definition of market value at pork}

The German meat industry takes increasingly interest in sorting of pork carcasses based on their actual market value. The market value of a carcass in the whole should be represented by the sum of values of all single cuts dissected from a carcass. These values of the single cuts are defined by their tissue composition and meat quality characteristics (i.e. colour, $\mathrm{pH}$, etc.), respectively. Therefore, the best approximation to the market value in practice seems to be the price at the level of wholesalers. Unfortu- 
nately, this price strongly depends on the market situation, the market position of the wholesaler, as well as on his marketing efficiency. Consequently, it is hardly to define objectively.

On the other hand, the fixing of market value at the slaughter line requires very quick methods that base on instrumental measurements and electronic data management. Finally, the data should be put into estimation formulae of the carcass composition criteria. The statistical calculation of estimation functions makes it necessary that only few carcass traits are selected as representatives of the market value, since the estimation error is summing up unavoidably. In case of the complete estimation of all single cuts the great number of single estimation errors would lead to an intolerable great total error, this would make the estimation unreliable.

An additional reason for limiting the number of criteria at the definition of the market value is that systems of producer prices must be simple and easy to verify.

These systems should give information not only about the whole carcass, but also about its most important components. Until now the lean meat percentage of the carcass seemed to be by far the strongest criterion. However, in the last years cut retailing is gaining more and more importance and reaches in modern abattoirs up to 90 per cent of the total market volume. That gives drive for a new type of marketing, based on the value of the cuts, with a better differentiation of biological variance in carcass proportions.

By selecting criteria, especially for pricing systems, the overlapping of information should be avoided as far as possible. Overlapping of information can be demonstrated the best by the determination coefficient $\left(r^{2}\right)$ between the criteria (Table 1).

Table 1

Common variance as a part of the total variance of some criteria of market value $\left(r^{2} * 100\right)(G e m e i n s a m e$ Varianz als Anteil an der Gesamtvarianz einiger Merkmale des Handelswertes)

\begin{tabular}{|c|c|c|c|c|c|}
\hline Trait & $\begin{array}{l}\text { Slaughter } \\
\text { weight }(\mathrm{kg})^{\mathrm{l}} \text {. }\end{array}$ & Lean (\%) & $\begin{array}{l}\text { Valuable cuts } \\
(\%)\end{array}$ & Lean (\%) by & $\operatorname{ham}(\mathrm{kg})$ \\
\hline & & & & \multicolumn{2}{|c|}{ Actual data from dissection } \\
\hline Slaughter weight (kg) & & 8,3 & 5,8 & 9,8 & 86,2 \\
\hline Lean, carcass (\%) & 10 & & 89,5 & 87,3 & $<1$ \\
\hline Valuable cuts (\%) & 9,1 & 86,7 & & 70,1 & $<1$ \\
\hline Lean (\%) belly & 15 & 94,3 & 78,4 & & $<1$ \\
\hline ham weight $(\mathrm{kg})$ & 90,3 & $<1$ & $<1$ & 2 & \\
\hline \multicolumn{5}{|c|}{ Estimation Autofom. } & \\
\hline
\end{tabular}

Evidently, the lean meat content of carcass has a very high common variance to all percentages, the slaughter weight however to the weight components. This fact is partially even more apparent in the estimation results of Autofom (Table 1, lower part). This diminishes the suitability of the two traits as predicting criteria in combination with other criteria. As it can be seen from the table, ideal combination partners are percentages on the one hand and weight components on the other hand.

A schematic example of the new pricing system regarding these ideas has been shown by BRANSCHEID and DOBROWOLSKI (1998). The most striking fact is that the 
criterion of the official grades (lean content of carcass) has been neglected. Instead of that, ham weight and lean content of the belly were combined. The slaughter weight has to keep only the weight limits, because over and under weights are very difficult to handle on the market. It is foreseen that a very similar type of pricing system will soon be established in Germany.

We can conclude that in the future it will be justified to give more attention to the market value basing on the single cuts, than to the official grades, which give only a rough and overall description of the carcass.

\section{Instrumental devices for determining the market value}

Nowadays four technically different types of instruments are available for the determination of market value in Germany:

- Opto-electronic devices: The measurements are carried out by penetrating into the carcass and determining the fat and muscle depth as differences in brightness of reflected light.

- Ultrasonic scanners: This non-invasive technique determines the limits between tissue components by sonography using linear or real time scanning. For purposes of grading they have to take the same fat and muscle depth as the opto-electronic devices (at the $2^{\text {nd }} / 3^{\text {rd }}$ last rib, $7 \mathrm{~cm}$ beside the midline). The estimation formulae for these instruments are calculated by stepwise regression. It is to be noticed that the national calibration apparatus for all the grading instruments is an ultrasonic scanner as well.

- Autofom (SFK company, DK): The Autofom is an ultrasonic scanner equipped with 16 transducers, which are arranged in an U-shaped array. The carcass has to be measured on the slaughter line between dehairing and singeing oven . More than 2.000 primary measures are taken, which are transformed into 127 fat and muscle depths in the dorsal region. From the data thirty ones are carefully selected for the calculations basing on the PLS method.

- The video imaging system VCS 2000 (e \& v, Oranienburg): The VCS 2000 is not admitted for grading in Germany and has been constructed especially for purposes of the value based marketing. With the aid of three cameras, the system measures 126 fat and muscle depth, length and width, as well as some angles and areas. The formulae are calculated by fore and backward stepwise regression. Normally six or seven traits are introduced as variables in the estimation functions. The apparatus at present is only available as a prototype.

\section{Comparison between different techniques}

The following comparison refers to three instruments:

- Fat-o-Meat'er (FOM; SFK, DK) as an example of an opto-electronic probe. In the trial it has been used under very exact experimental conditions.

- VCS 2000 (e \& v, Oranienburg). The same sample of carcasses ( $n=142$, BRANSCHEID et al., 1999) has been used for FOM and VCS 2000 simultaneously (Table 2). 
- Autofom (SFK, DK). The sample ( $\mathrm{n}=148$, BRANSCHEID et al., 1997) is different from the former one, however it is well comparable by its characteristics (slaughter weight, fat depth) (Table 2).

As the VCS 2000 can not be used as grading apparatus, it is well worth seeing its combination with the FOM. This combination [VCS + FOM] is included in the comparison. All formulae are calculated including slaughter weight directly or in transformation (e. g. quotient with other traits).

The first group of market value criteria are the weights of the primal cuts (Table 3). In the tables the correlation (R) and the residual standard deviation (RSD) of estimation are given. Additionally the relative RSD (RSD \%) is shown as a percentage of the standard deviation from the mean of the respective trait. This parameter is a reliable measure for the practical applicability of the estimation. If the estimation error RSD exceeds the standard deviation, the estimation is quite unsuitable. Good estimations should have a relative estimation error of less than $50 \%$.

Table 2

Characteristics of the different samples used in the estimations of market value (Ausprăgung der Merkmale in den fur die Handelswertschătzungen verwendeten Stichproben)

\begin{tabular}{|c|c|c|}
\hline Item & $\begin{array}{l}\text { Sample } \\
\text { FOM/VCS } 2000 \\
\mathrm{x}(\mathrm{s})\end{array}$ & $\begin{array}{l}\text { Autofom } \\
\mathrm{x}(\mathrm{s})\end{array}$ \\
\hline $\begin{array}{l}\text { number }(\mathrm{n}) \\
\text { weights (kg) }\end{array}$ & 142 & 148 \\
\hline - ham & $11,9(1,47$ & $12,1(1,43)$ \\
\hline - loin & $5,9(0,83)$ & $5,8(0,75)$ \\
\hline - shoulder & $6,3(0,74)$ & $6,2(0,74)$ \\
\hline - belly & $4,8(0,68)$ & $4,9(0,72)$ \\
\hline - ham (ret.' $)$ & $8,9(1,27)$ & $9,2(1,17)$ \\
\hline - loin (ret. ${ }^{\prime}$ ) & $3,6(0,58)$ & $3,5(0,50)$ \\
\hline - tender loin & $0,7(0,11)$ & $0,7(0,11)$ \\
\hline $\begin{array}{l}\text { - shoulder (ret. }{ }^{1 .} \text { ) } \\
\text { proportions (\%) }\end{array}$ & $4,7(0,60)$ & $4,4(0,52)$ \\
\hline - ham & $25,6(1,18)$ & $26,0(1,15)$ \\
\hline - loin & $12,7(0,90)$ & $12,6(0,70)$ \\
\hline - shoulder & $13,6(0,57)$ & $13,3(0,52)$ \\
\hline - belly & $10,3(0,74)$ & $10,5(0,68)$ \\
\hline - lean in the belly & - & $51,6(5,73)$ \\
\hline
\end{tabular}

The estimation of the primal cut weight reaches high accuracy at all instruments. There is strong evidence that the slaughter weight as a predictor has a positive effect on correlation and estimation error. A remarkable advantage can be observed for Autofom in the loin and in shoulder, whereas the estimation in ham and belly is more exact with the VCS 2000. The combination [VCS + FOM] is useful especially in the loin, because FOM takes measures in that region which is unattainable for VCS 2000.

Generally, the estimation error in most cases is so low, that a good differentiation of three or four weight classes can be performed within the variance available. 
By estimating the weight of the retail cuts, a certain drop occurs only in some cases at the estimation accuracy (Table 4).

Table 3

Estimation of the weight $(\mathrm{kg})$ of the primal cuts with different techniques (Schatzung des Gewichts $(\mathrm{kg})$ der Hauptteilstulke mit verschiedenen Techniken)

\begin{tabular}{|c|c|c|c|c|c|c|c|c|c|c|c|c|}
\hline \multirow{2}{*}{$\begin{array}{c}\text { Carcass } \\
\text { trait }\end{array}$} & \multicolumn{3}{|c|}{ FOM } & \multicolumn{3}{|c|}{ VCS 2000} & \multicolumn{3}{|c|}{ [VCS + FOM] } & \multicolumn{3}{|c|}{ Autofom } \\
\hline & $\mathrm{R}$ & RSD & $\begin{array}{c}\text { RSD } \\
\% \\
\end{array}$ & $\mathrm{R}$ & RSD & $\begin{array}{c}\text { RSD } \\
\% \\
\end{array}$ & $\mathrm{R}^{2}$ & RSD & $\begin{array}{c}\text { RSD } \\
\% \\
\end{array}$ & $\mathrm{R}$ & RSD & $\begin{array}{c}\text { RSD } \\
\% \\
\end{array}$ \\
\hline ham & .95 & 0.46 & 31.3 & .98 & 0.31 & 21.1 & .98 & 0.28 & 19.1 & .96 & 0.38 & 26.6 \\
\hline loin & .94 & 0.29 & 34.9 & .94 & 0.30 & 36.1 & .95 & 0.26 & 31.3 & .97 & 0.19 & 25.3 \\
\hline shoulder & .94 & 0.25 & 33.8 & .95 & 0.23 & 31.1 & .95 & 0.23 & 31.1 & .97 & 0.16 & 21.6 \\
\hline belly & .91 & 0.29 & 42.7 & .93 & 0.26 & 38.2 & .93 & 0.25 & 36.8 & .97 & 0.29 & 40.3 \\
\hline
\end{tabular}

Table 4

Estimation of the weight $(\mathrm{kg})$ of the retail cuts with different techniques (Schătzung des Gewichts $(\mathrm{kg})$ der zugeschnittenen Teilstulcke mit verschiedenen Techniken)

\begin{tabular}{|c|c|c|c|c|c|c|c|c|c|c|c|c|}
\hline \multirow{2}{*}{$\begin{array}{c}\text { Carcass } \\
\text { trait }\end{array}$} & \multicolumn{3}{|c|}{ FOM } & \multicolumn{3}{|c|}{ VCS 2000} & \multicolumn{3}{|c|}{ [VCS + FOM] } & \multicolumn{3}{|c|}{ Autofom } \\
\hline & $\mathbf{R}$ & RSD & $\begin{array}{c}\text { RSD } \\
\%\end{array}$ & $\mathrm{R}$ & RSD & $\begin{array}{c}\text { RSD } \\
\%\end{array}$ & $\mathbf{R}$ & RSD & $\begin{array}{c}\text { RSD } \\
\%\end{array}$ & $\mathrm{R}$ & RSD & $\begin{array}{c}\text { RSD } \\
\%\end{array}$ \\
\hline $\begin{array}{l}\text { ham } \\
\text { (ret. }{ }^{1} \text { ) }\end{array}$ & .94 & 0.44 & 34.7 & .96 & 0.38 & 29.9 & .97 & 0.32 & 25.2 & .96 & 0.31 & 26.5 \\
\hline $\begin{array}{l}\text { loin } \\
\text { (ret.') }\end{array}$ & .93 & 0.22 & 37.9 & .90 & 0.25 & 43.1 & .94 & 0.20 & 34.5 & .95 & 0.15 & 30.0 \\
\hline $\begin{array}{l}\text { tender } \\
\text { loin }\end{array}$ & .88 & 0.05 & 46.4 & .88 & 0.05 & 45.5 & .90 & 0.05 & 45.5 & .88 & 0.05 & 46.5 \\
\hline $\begin{array}{c}\text { shoulder } \\
\text { (ret.') }\end{array}$ & .93 & 0.23 & 38.3 & .93 & 0.23 & 38.3 & .94 & 0.21 & 35.0 & .95 & 0.15 & 28.9 \\
\hline
\end{tabular}

Especially the tender loin demonstrates clearly the limits of weight estimations for all instruments by its relative estimation error of nearly $50 \%$. However, considering the relatively high correlation at the same time, the estimations are still valid. For the other cuts the Autofom gives somewhat better results than VCS 2000, but the combination [VCS + FOM] significantly reduces this advantage. Generally, we may conclude that the estimation is valid enough to differentiate two to four weight classes of the retail cuts.

The estimation of the proportion of primal cuts (\%) is far more complicated than the estimation of weight components (Table 5). This is a well-known fact at other traits, too. Only the estimation of ham proportion by VCS 2000 and the combined system reach sufficient estimation accuracy. The other estimations can only be used for predictions referring to groupings of carcasses (e. g. genotypes or different feedings), but not for single carcasses. In groupings the estimation error drops drastically, but because of the relatively low correlations these estimation formulae should be tested in a field trial before using them in deciding process for the supplier evaluation or the feeding and breading assistance.

The proportion of lean in belly is shown in case of Autofom. This estimation can't be done at present by VCS 2000, because the reference data from the dissection of belly are not yet available. Nevertheless, the results of Autofom evidently demonstrate that by its relatively high estimation error this estimation is of limited value only. 
Table 5

Estimation of the proportion (\%) of primal cuts with different techniques (Schătzung des Anteils (\%) der Hauptteilstucke mit verschiedenen Techniken)

\begin{tabular}{|c|c|c|c|c|c|c|c|c|c|c|c|c|}
\hline \multirow{2}{*}{$\begin{array}{c}\text { Carcass } \\
\text { trait }\end{array}$} & \multicolumn{3}{|c|}{ FOM } & \multicolumn{3}{|c|}{ VCS 2000} & \multicolumn{3}{|c|}{ [VCS + FOM] } & \multicolumn{3}{|c|}{ Autofom } \\
\hline & $\mathrm{R}$ & RSD & $\begin{array}{c}\text { RSD } \\
\%\end{array}$ & $\mathrm{R}$ & RSD & $\begin{array}{c}\text { RSD } \\
\%\end{array}$ & $\mathrm{R}$ & RSD & $\begin{array}{c}\mathrm{RSD} \\
\%\end{array}$ & $\mathrm{R}$ & RSD & $\begin{array}{c}\text { RSD } \\
\%\end{array}$ \\
\hline ham & .67 & 0.89 & 75.4 & .83 & 0.67 & 56.8 & .86 & 0.62 & 52.5 & .72 & 0.80 & 69.6 \\
\hline loin & .72 & 0.62 & 68.9 & .72 & 0.64 & 71.1 & .79 & 0.56 & 62.2 & .69 & 0.51 & 72.9 \\
\hline shoulder & .33 & 0.54 & 94.7 & .55 & 0.49 & 86.0 & .56 & 0.48 & 84.2 & .37 & 0.48 & 92.3 \\
\hline $\begin{array}{l}\text { belly } \\
\text { lean }\end{array}$ & .57 & 0.61 & 82.4 & .67 & 0.56 & 75.9 & .70 & 0.54 & 73.0 & .51 & 0.58 & 85.3 \\
\hline $\begin{array}{l}\text { content } \\
(\%) \text { in } \\
\text { the } \\
\text { belly }\end{array}$ & - & - & - & - & - & - & - & - & - & .88 & 2.69 & 46.9 \\
\hline
\end{tabular}

\section{Conclusions}

The four technical systems presented in this study seem to give equally good results in predicting the market value of pork carcasses. However, it should be considered that the Fat-o-Meat'er (FOM) had been used under experimental conditions while the other instruments had been working online under practical circumstances. It is to be noticed, that the operator has a considerable influence on the accuracy of measurements and therefore on the validity of estimation. Consequently, it is not recommended to refer to the FOM at carcass traits with lower estimation accuracy.

Also for the VCS 2000 there exist some limitations because at the moment it is only a prototype and a test of repeatability and reproducibility of the measuring technique has to be done with the actually installed instrument.

The two fully automatic apparatuses Autofom and VCS 2000 are more or less equivalent for practical purposes. The fully automated measuring process makes it possible to eliminate most of the external influences on the measuring accuracy.

Despite the high level of reproducibility of Autofom (BUSK et al., 1999), in Germany a special calibration of all single Autofom apparatuses is prescribed with respect to their individual situation in the slaughter line. It is founded on the fact, that e.g. the positioning of carcass in the U-shaped array depends on the geometry of the slaughter line and may influence the grading results. This connection may become obvious by evaluating a greater number of carcasses. Controlling the devices in this way, they give highly reliable results at any time and under different conditions. Moreover, the results will be exactly the same under practical conditions as under experimental circumstances. That makes the fully automated instruments even more exact than it is expressed by the statistical evidence. The philosophy sounds as follows: more controlling before grading and less after that. However, this philosophy needs a very sophisticated and conclusive controlling concept, which should be built up carefully.

At the moment a similar concept doesn't exist for the VCS 2000. But it seems very likely that it is necessary to develop something comparable for all fully automatic functioning apparatuses to assure the correct measuring in advance. 
From the carcass traits presented here only the weight components are estimated satisfactorily. In the past, the scientific literature paid more attention to the carcass proportions (\%), but the economic practice successively gained more interest in weight components. Evidently, the weight of the ham is more important for marketing, than its proportion within the carcass. Consequently, it is easy to understand that the slaughtering industry begins to consider systems of producer pricing, which lay more emphasis on the weight components. From the industrial point of view, these give the right market signals. However, a new problem arises for the producers this way, because the information in form of weight components of the carcass can practically not converted into consequences for breeding or feeding activities. For these types of activities standardised data are necessary, which are comparable between different groupings and especially independent of slaughter weight. Such data should be expressed in form of percentages or similar relative numbers. Therefore despite the fact, that generally the estimation accuracy is relatively low for the carcass proportions and possibly they will not be part of future producer pricing, a direct feed back to the producer about the expression of these traits will absolutely be necessary. This supposes the willingness of the meat industry to collaborate.

As a conclusion we can state, that the fully automatic devices represent a new stage of development. They are calculating the market value on a great number of measurements and in most aspects with high reliability. This is possible because their estimation functions are optimised on the basis of a wide-ranging statistical information. The newly attainable criteria will finally lead to better differentiated producer pricing systems and at last to a more consumer-friendly production.

\section{References}

BRANSCHEID, W.; DOBROWOLSKI, A.; HÖRETH, R.:

Bestimmung der Handelsklassen und des Handelswertes von Schweinehălften mit dem Gerăt Autofom. Fleischwirtschaft 77 (1997), 619-622

BRANSCHEID, W.; DOBROWOLSKI, A.; HÖRETH, R.:

Video Image-Analyse als Methode zur automatischen Handelswertbestimmung von Schweinehälften. Fleischwirtschaft 79 (1999) 12, 93-95

BUSK, H.; E. V. OLSEN, E.V.; BRØNDUM, J.:

Determination of lean meat in pig carcasses with the Autofom classification system. Meat Science 52 (1999), 307-314

Received: 1999-06-21

Accepted: 2000-02-01

Authors' address

Prof. Dr. WOLFGANG BRANSCHEID, Dipl.-Phys. ANDREAS DOBROWOLSKI

Federal Centre for Meat Research

Institut for Meat Production and Market Research

E.C.-Baumann-Str. 20

D-95326 Kulmbach

Germany 
Arch. Tierz., Dummerstorf 43 (2000) 2, 138

\title{
Buchbesprechung
}

\author{
Populationsőkologie \\ MICHAEL BEGON, MARTIN MORTIMER und DAVID J. THOMPSON
}

380 Seiten, 25 Tabellen, 196 Abbildungen, Spektrum Akademischer Verlag, Heidelberg, Berlin, Oxford,1997, ISBN 3-86025-258-5, 78,00 DM; 570,00 OS; 71,00 SFr

Aus dem Englischen kompetent übersetzt von J. Muller und A. Seitz, liegt nun in deutscher Sprache die dritte Auflage dieses Buches mit einem Thema vor, zu welchem im deutschsprachigen Raum bisher wenig Literatur verfugbar ist. Sicherlich begrllndet sich dies aus der historischen Entwicklung der Populationsökologie, wobei in jüngerer Zeit zunehmend angewandte Fragen der Populationsbiologie ins Blickfeld rücken. Genannt seien z.B. die Empfehlungen zum Schutz vom Aussterben bedrohter Tier- und Pflanzenarten oder die Optimierung der Möglichkeiten, aber auch Grenzen der biologischen Bekämpfung von Schädlingen und Unkräutern bis zur Wertung 6 kologischer Fragen zu gentechnisch verănderten Organismen. Das vorliegende Buch leistet hierbei einen Beitrag und versucht anwendungsorientiert grundlegende Erkenntnisse der Populationsø̋kologie zu vermitteln. Die Autoren untersuchen, unterlegt mit zahllosen Beispielen, Größen und Verteilungen von Pflanzenund Tierpopulationen sowie die Prozesse insbesondere die biologischen die diese Größen bestimmen.

Das Buch ist in drei Teilen angelegt. Der erste beginnt mit den einfachsten grundlegenden Prinzipien und untersucht die Dynamik und Wechselwirkungen, die innerhalb der Populationen einzelner Arten auftreten. Ausgehend von den Abschnitten zur Beschreibung von Populationen werden im zweiten Abschnitt die innerartliche Konkurrenz und im dritten Modelle für Populationen einzelner Arten dargestellt. Der zweite umfangreiche Buchteil beschäftigt sich mit interspezifischen Wechselwirkungen, mit zwischenartlicher Konkurrenz und den Rauber-Beutesystemen (Prädation) bis zum Unterabschnitt Ernte (Eingriff) durch den Menschen. Der letzte Buchteil beinhaltet Fragen der Regulation und Bestimmung der Populationsgrőe bis zum Unterabschnitt Chaos im ökologischen System, des Konzeptes der Metapopulation und der Bedeutung von Wechselwirkungen innerhalb und zwischen Populationen für die Bestimmung der Struktur von Lebensgemeinschaften. Das Buch schließt mit einem überwiegend aus dem englischen Sprachraum stammenden umfangreichen Literaturverzeichnis, einem Organismen- und einem Sachregister. Da die Populationsőkologie unvermeidlich auch eine numerische und quantitative Angelegenheit ist, finden sich wo notwendig, Mathematik und Modelle meist im letzten Teil der jeweiligen Abschnitte.

Im Buch werden in umfassender Weise die ökologischen Prinzipien, die sowohl die Struktur einer Gruppe von Lebewesen als auch die zugrunde liegenden biologischen Prozesse bestimmen, dargestellt. Es ist klar gegliedert, ubersichtlich, in einer verstăndlichen Sprache geschrieben und liest sich flussig. Zum besseren Verständnis tragen maßgeblich die zahlreichen Übersichten und Abbildungen bei.

Dieses Standardlehrbuch stellt einen unverzichtbaren Beitrag zu dem sich rasch entwickelnden Gebiet der Populationsbiologie dar. Es eignet sich sowohl für Studierende biologischer, okologischer und agrarwissenschaftlicher Fachgebiete als auch Ökologen, die in aktuellen Forschungen, Untersuchungen zu den Beziehungen zwischen Arten, Individuen und Populationen integrieren möchten.

ERNST RITTER, Dummerstorf 